PRODUCTION

ENGINEERING ARCHIVES
2016, Vol. 13, No. 4, pp 35-40

ISSN 2353-5156

ISSN 2353-7779 (print version)

(online version)

Article history: $\quad$ Received: 05.12.2016

Accepted: 11.12.2016

Online: 30.12 .2016

Available online on: http://www.qpij.pl

Exist since $4^{\text {th }}$ quarter 2013

\title{
Integration management system - new of requirements of ISO 9001:2015 and ISO 14001:2015 standards
}

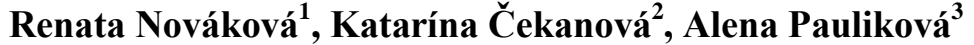 \\ ${ }^{1}$ Slovak university of technology in Bratislava, Faculty of materials science and technology in Trnava, Institute of Industrial Engineering and \\ Management, Paulínska 16, 91724 Trnava, email: renata.novakova@stuba.sk \\ ${ }^{2}$ Slovak university of technology in Bratislava, Faculty of materials science and technology in Trnava, Institute of Industrial Engineering and \\ Management, Paulínska 16, 91724 Trnava, email: katarina.cekanova@stuba.sk \\ ${ }^{3}$ Slovak university of technology in Bratislava, Faculty of materials science and technology in Trnava, Institute of Industrial Engineering and \\ Management, Paulínska 16, 91724 Trnava, email: alena.paulikova@stuba.sk
}

Abstract. Organizations are becoming more aware of the importance of integrated management systems (IMS). Interest in this subject indicates that IMS are seen as "management systems of the future". The problem is that the methodology of integration of management systems does not exist. There are specification for example PAS 66 that tell only about requirements standards. standards Both ISO 9001:2015 and ISO 14001:2015 standards were revised in 2015. Based on this, the aim of this article is to characterize the possibility of creation of IMS through the identification of common elements and specific requirements in accordance with professional references ISO 9001:2015 and ISO 14001:2015.

Key words - Integrated management system, environmental management system, quality management system

\section{General requirements}

According to the Chartered Quality Institute, UK, integration means a combination; that is putting all the internal management practices into one system in such a way that the components of the system are not separated but linked to form one integral part of the company's management system. In simple words, an integrated management system (IMS) is a management system which combines all components of a business into one coherent system so as to enable the achievement of it purpose and mission (OlARU M., MAIER D., NiCOARA D., MAIER A. 2013).
The most common integrated international standards include are: Quality Management Systems (QMS) according to ISO 9001, Environmental Management Systems (EMS) according to ISO14001 or EMAS III, and Occupational health and safety management systems according to OHSAS 18001. Integration of three management systems is possible because ISO 9001 and ISO 14001 standards are compatible and OHSAS 18001 specification was modelled on ISO 14001; all of them have a process oriented approach based on the concept PDCA (Plan - Do - Check - Act). Effective management is based on maintaining and improving standards. The first task should be to maintain management standards based on the cycle of SDCA (standardize - do - check - act). When standards are adhered 
to by employees, the next task should be to improve the standards based on the PDCA cycle (plan - do check - act) (JAGUSIAK-KOCIK M. 2014, KNOP K., MIELCZAREK K. 2015).

The ultimate focus of ISO 9001 is profit intended to improve customer satisfaction. EMS, according to ISO 14001, is focused on how the company cares about the environment (standard towards the outside). An important term which relates to EMS is sustainability. Sustainability is broadly defined as meeting the needs of the present generation without compromising the ability of future generations to meet their own needs (INGALDI M., 2015 STASIAK-BETLEJEWSKA 2015). OHSAS is focused on how management manages their employees (standard towards inside). These can also integrate other standards such as: ISO 27001 (Information security), ISO 26000 (Social responsibility), ISO 31000 (Risk management), or different industry standards ISO 50001 (Energy management), ISO 22000 (Food safety management systems), ISO 13485 (Medical devices), ISO/TS 16949 (Automotive quality management), etc., as well as internal standards developed by the company itself and valid within (IKEA, SONY, Slovnaft). ISO/TS 16949 together with ISO 9001 demonstrate guidelines for the implementation and maintenance of quality management systems in the whole chain of production processes and the production of spare parts in the automotive industry (ROSAKSZYROCKA J. 2014).

Integrating two or more management systems into an integrated management system can have much advantages: alignment of objectives, processes, resources in different areas, reducing of paper work, eliminating of duplications between procedures of the systems, reduction in external certification costs over single certification audits, a holistic approach to managing business risks, improvement of internal and external communication, increase of management efficiency by merging three functional departments into one, time saving, better structured processes and clearer responsibilities, improved operational performance, crossfunctional team work and integrated audits. It is a time consuming and costly process. The integration of systems arise to certain risks. One of them is giving different importance to each aspect, for example more attention is paid to aspects of quality at the expense of environmental aspects. It is important to remember that integration of systems does not mean that these systems will exist next to each other but have to be connected with each other and to form a complete unit. For integration is therefore not use the software package documentation administering the systems, or the inclusion of managers for QMS, EMS and OHSAS per one department.

\section{Requirements of ISO 9001:2015 and ISO 14001 standards}

In the year 2015 the new international standards ISO 9001:2015 and ISO 14001:2015 were published. In the year 2017 standard for Occupational Health and Safety Management Systems (ISO 45001) will be published. The similarities or the generic processes in a management system are: top management commitment, definition of a policy, planning of objectives and targets, procedures for training of employees, communication procedures, audits, documentation and records control, control of non-compliance, corrective and preventive actions, and management review. In the Table 1 similarities and specifications in management are presented. There are several approaches which can be taken, depending on the current position of an organisation.

Conversion: If an organisation has a certificated QMS, it can build upon it by adding the necessary processes to cater for health, safety, environment, and other requirements of management system standards.

Merging systems: If an organisation has more than one formal system, e.g. a quality management system and an environmental management system, it can merge these two systems and proceed to integrate other systems as it begins their formalisation. With this method the organisation can merge documentation where it supports the same process. However, they will remain two separate systems unless the labels are removed, and quality, safety and environment are no longer separated at the detail level.

System engineering approach: Whether an organisation has an existing formal system or no formal system, it can adopt the system engineering approach to management system development, i.e. design a system top-down to fulfil a specific objective. The benefits are that one coherent system can be built which serves business needs and does not tie the organisation to a particular standard (DOUGLAS A., GLEN D. 2000). 
Table 1. Overview of similarities of standards ISO 9001:2015 and ISO 14001:2015

\begin{tabular}{|c|c|}
\hline \multicolumn{2}{|r|}{ SIMILARITIES OF MANAGEMENT SYSTEMS (QMS, EMS) } \\
\hline $\begin{array}{c}\text { Context of the } \\
\text { organization }\end{array}$ & $\begin{array}{l}\text { The organization: } \\
-\quad \text { should determine external and internal issues, monitor and review information about that issues. } \\
-\quad \text { should determine interested parties and requirements of the interested parties to the quality management system } \\
\text { (QMS) and environmental management system (EMS). The organization shall monitor and review information } \\
\text { about interested parties. } \\
\text { - } \\
\text { should determine the scope of QMS and EMS. It means that the organization shall determine the boundaries of } \\
\text { applicability of QMS and EMS (free choice, throughout the organization or in selected parts of the organization). } \\
-\quad \text { should not exclude from the scope of activities the ones that have a significant impact on strategy or environment. } \\
-\quad \text { should determine the applicability of QMS/EMS. When the applicable requirements of the standard an organization } \\
\text { must substantiate this decision. } \\
\text { should determine the processes for QMS/EMS, determine the inputs and outputs from these processes, determine } \\
\text { the interaction of these processes, evaluate the performance, determine the resources and ensure their availability, } \\
\text { assign the responsibilities and authorities for processes and address the risk and improve the processes. }\end{array}$ \\
\hline Leadership & $\begin{array}{l}\text { Top management should: } \\
\text { - } \text { demonstrate leadership. } \\
\text { - } \text { take responsibility for the effectiveness of QMS/EMS. } \\
-\quad \text { establish, implement and maintain an policy and objectives for QMS/EMS. The policy shall be available to rele- } \\
\text { vant interested parties, shall be maintained and communicated. } \\
\text { - } \text { provide the resources needed for QMS/EMS. } \\
-\quad \text { ensure the requirement of QMS/EMS integration into the organization's business processes. } \\
-\quad \text { assign the responsibility and authority for the following: } \\
\quad-\quad \text { ensuring that QMS/EMS conform to the requirements of standards ISO 9001:2015/ISO 14001:2015. } \\
\text { - } \text { reporting on the performance of QMS/EMS. }\end{array}$ \\
\hline Planning & $\begin{array}{l}\text { The organization should: } \\
\text { - determine the risk and opportunities related to intended results of QMS and environmental aspects. } \\
\text { - } \text { plan and implement actions to address of risks and opportunities and evaluate the effectiveness of these actions. } \\
-\quad \text { establish quality and environmental objective at relevant functions, levels and processes. The objectives should be } \\
\text { consistent with the policy, shall be measurable, communicated and update. } \\
-\quad \text { plan changes in QMS/EMS and review the consequences of change. It means defining the purpose of the change, } \\
\text { the availability of resources, reallocation of responsibilities and authorities, etc.. } \\
\text { - } \text { determine and provide the resources needed for QMS/EMS. }\end{array}$ \\
\hline $\begin{array}{l}\text { Support and } \\
\text { operation }\end{array}$ & $\begin{array}{l}\text { The organization should: } \\
-\quad \text { determine and provide the resources needed for QMS/EMS. } \\
\text { - determine the competence that is necessary in terms of people, take actions to acquire the competence and evaluate } \\
\text { the effectiveness of the action taken. } \\
\text { - ensure that person doing work under the organization's control is aware of the environmental and qualitative pol- } \\
\text { icy, the quality objectives, the significant environmental aspects and their contribution to the effectiveness of } \\
\text { QMS/EMS. } \\
-\quad \text { establish the process needed for internal and external communications relevant to QMS/EMS. } \\
-\quad \text { control the processes and determine the requirement for the processes, the products and services and establish crite- } \\
\text { ria for the processes. } \\
-\quad \text { control outsourced processes. }\end{array}$ \\
\hline $\begin{array}{l}\text { Performance } \\
\text { evaluation }\end{array}$ & $\begin{array}{l}\text { The organization should: } \\
-\quad \text { evaluate the effectiveness of QMS/EMS. The organization ought to determine what needs to be monitored and } \\
\text { measured, the methods for measurement, time of measurement and shall evaluate the performance QMS/EMS. } \\
-\quad \text { conduct internal audits at planned intervals. } \\
-\quad \text { review the organization's quality management system and environmental management systems at planned intervals. }\end{array}$ \\
\hline Improvement & $\begin{array}{l}\text { The organization is supposed to determine and select opportunities for improvement. } \\
\text { When nonconformity occurs, the organization ought to react to it, by reviewing and analysing, as well as determining } \\
\text { its causes. It should also undertake any actions needed, review the effectiveness of any corrective action taken and } \\
\text { update risks }\end{array}$ \\
\hline
\end{tabular}


Renata Nováková, Katarína Čekanová, Alena Pauliková, Integration management system..., Vol. 13(4)/2016

Table 2. Overview of specifications of standards ISO 9001:2015 and ISO 14001:2015

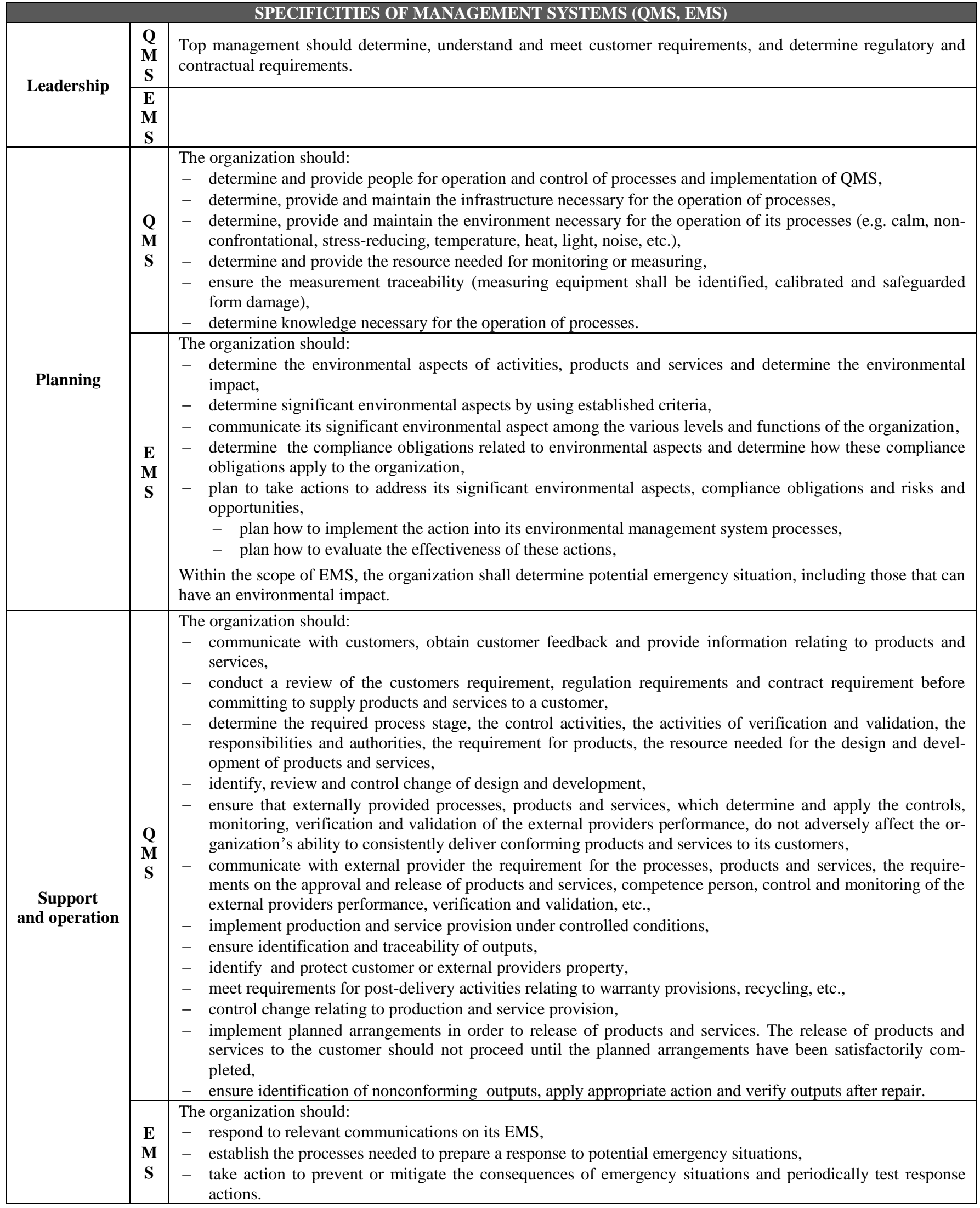




\begin{tabular}{|c|c|c|}
\hline \multirow[b]{2}{*}{$\begin{array}{l}\text { Performance } \\
\text { evaluation }\end{array}$} & $\begin{array}{l}\mathbf{Q} \\
\mathbf{M} \\
\mathbf{S}\end{array}$ & $\begin{array}{l}\text { The organization should: } \\
-\quad \text { monitored of customer satisfaction, } \\
-\quad \text { analyse and evaluate appropriate data from monitoring and measurement. }\end{array}$ \\
\hline & $\begin{array}{c}\mathbf{E} \\
\mathbf{M} \\
\mathbf{S}\end{array}$ & $\begin{array}{l}\text { The organization should: } \\
\text { - monitor, measure, analyse and evaluate its environmental performance and determine the criteria of evalu- } \\
\text { ate, } \\
-\quad \text { communicate relevant environmental performance information both internally and externally, } \\
-\quad \text { establish, implement and maintain the process needed to evaluate fulfilment of its compliance obligation. }\end{array}$ \\
\hline \multirow{2}{*}{ Improvement } & $\begin{array}{c}\mathbf{Q} \\
\mathbf{M} \\
\mathbf{S}\end{array}$ & \\
\hline & $\begin{array}{l}\mathbf{E} \\
\mathbf{M} \\
\mathbf{S}\end{array}$ & \\
\hline
\end{tabular}

Table 3. Overview of requirements on documentation information (ISO 9001:2015, ISO 14001:2015)

\begin{tabular}{|c|c|c|}
\hline \multicolumn{3}{|r|}{ DOCUMENTED INFORMATION } \\
\hline $\begin{array}{l}\text { Similar re- } \\
\text { quirements }\end{array}$ & & $\begin{array}{l}\text { ganization should retain documented information in terms of: } \\
\text { e scope of the quality management systems (QMS) and environmental management system (EMS), } \\
\text { le quality policy and environmental policy, } \\
\text { e objectives for QMS/EMS (the organization shall determine: what will be done, what resources will be re- } \\
\text { uired, who will be responsible, when it will be completed, how the results will be evaluated), } \\
\text { e risk and opportunities, } \\
\text { le processes of QMS/EMS (inputs, outputs, performance evaluation, resource, responsibility and authority, etc.), } \\
\text { ecessary competence of people doing work under the control that affect the performance of QMS/EMS, } \\
\text { e documented information that demonstrate that processes have been carried out as planned, } \\
\text { erformance evaluation of QMS/EMS, } \\
\text { e audit programme, } \\
\text { le management review, } \\
\text { e control of nonconformity. }\end{array}$ \\
\hline \multirow[t]{2}{*}{$\begin{array}{l}\text { Specific requ- } \\
\text { irements }\end{array}$} & $\begin{array}{c}\mathbf{Q} \\
\mathbf{M} \\
\mathbf{S}\end{array}$ & $\begin{array}{l}\text { The organization should retain documented information on the following: } \\
-\quad \text { the resources of monitoring and measurement, } \\
-\quad \text { the necessary knowledge, } \\
-\quad \text { the control of externally provided processes, products and services, } \\
-\quad \text { demonstrating fraceability, } \\
-\quad \text { lost or damaged property of a customer or an external provider, } \\
-\quad \text { the results of the review of change, } \\
-\quad \text { the release of products and services, } \\
-\quad \text { the control of nonconforming outputs, } \\
-\quad \text { the documented information needed to demonstrate that design and development requirements have been } \\
\text { met (documented information on design and development inputs, controls, outputs and change). }\end{array}$ \\
\hline & $\begin{array}{c}\mathbf{E} \\
\mathbf{M} \\
\mathbf{S}\end{array}$ & $\begin{array}{l}\text { The organization should retain documented information on: } \\
-\quad \text { the environmental aspects, and environmental impact, } \\
-\quad \text { the significant environmental aspects and criteria used to determine its. significant environmental aspects, } \\
-\quad \text { the compliance obligations related to environmental aspects, } \\
-\quad \text { communications, } \\
-\quad \text { emergency preparedness and response, } \\
-\quad \text { the evaluation of compliance. }\end{array}$ \\
\hline
\end{tabular}

\section{Conclusion}

Integration of management systems into a single IMS brings many benefits to the organization. It is important to recognize, that IMS is a single structure used by organizations to manage their processes or activities that transform input of resources into a product or service which meet the organization's objectives and equitably satisfy the stakeholders quality, health, safety, environmental, security, ethical or any other identified requirement. If this conditions not met, for example in favouring one system over another may develop risk. The results of several international studies show that the most companies implemented ISO 9001:2000 first, followed by ISO 14001: 2004, and then OHSAS 18001:1999. 
In Slovakia such a study has not been conducted. Studies have also shown the problems with integration have a small and medium-sized enterprises (SMEs) (Douglas A., GLEN D. 2000). SMEs referred the lack of time, human and financial resources, and the perception that that management systems are too bureaucratic. In general, SMEs are not aware that the adoption of IMS not only improves their management and their internal efficiency, but also results in cost reduction.

\section{Acknowledgment}

This paper was written with the financial support of the granting agency KEGA of The Ministry of Education, Science, Research and Sport of the Slovak Republic as a part of the project No. 074TUKE - 4/2015 - An innovative approach to legislative coordination of environmental protection through the visualization on the basis of the phenomenon Small World Networks.

\section{Literature}

1. Chartered Quality Institute. Integrated management systems. http://www.thecqi.org/Knowledge-Hub/ Resources/Factsheets/Integrated-management-systems/

2. Douglas A., Glen D. 2000. Integrated management systems in small and medium enterprises. Total Quality Management. 11 (4/5/6), 686-90.

3. INGALDI M. 2015. Sustainability as an element of environmental management in companies. Production Engineering Archives. 7 (2), 29-32.

4. ISO 14001:2015. Environmental management systems. Requirements with guidance for use.

5. ISO 9001:2015. Quality management systems. Requirements.

6. JAGUSIAK-KocIK M. 2014. Ensuring continuous improvement processes through standardization in the automotive company. Production Engineering Archives. 2 (1), 12-15.

7. Olaru M., Maier D., Nicoara D., Maier A. 2013. Establishing the basis for development of an organization by adopting the integrated management systems: comparative study of various models and concepts of integration. Procedia - Social and Behavioural Sciences, 693-697.
8. RoSAK-SZYrockA, J., BorkowsKI, S. 2014. ISO/TS 16949 system in quality aspect. Production Engineering Archives. 5 (4), 22-25.

9. StASIAK-BetlejeWSKA R. 2015. Value Engineering and Quality Management - Comparison. Quality and Competitiveness. $16^{\text {th }}$ International Symposium on Quality. Croatian Quality Managers Society. Zagreb.

10. KNOP K., MiELCZAREK K. 2015. The Improvement on the Basis of PDCA and SDCA Cycles. In: Quality Improvement Practice in Different Branches. Borkowski S., Rosak-Szyrocka J. (Ed.). Oficyna Wydawnicza Stowarzyszenia Menedżerów Jakości i Produkcji. Częstochowa. 